\begin{tabular}{|l|l|l|l|l|l|}
\hline J. Tek. Ling & Vol.10 & No.3 & Hal. 241 - 248 & Jakarta, Sept 2009 & ISSN 1441-318X \\
\hline
\end{tabular}

\title{
RESPON PENAMBAHAN EFFECTIFE MICROORGANISM-4 (EM-4) TERHADAP KUALITAS NUTRISI FERMENTASI LIMBAH BAGASSE TEBU UNTUK PAKAN TERNAK
}

\author{
A. Fariani ${ }^{1}$ dan Sindu Akhadiarto $^{2}$ \\ ${ }^{1}$ Program Studi Nutrisi dan Makanan Ternak \\ Fakultas Pertanian Universitas Sriwijaya \\ ${ }^{2}$ Pusat Teknologi Produksi Pertanian, Badan Pengkajian dan Penerapan Teknologi
}

\begin{abstract}
The objective of this research was to obtain the best dosage of using EM-4 in sugar cane waste. This research was done in two processes. First process was fermentation of sugar cane waste within 9 days in "Nutrisi dan Makanan Ternak" Laboratory at Sriwijaya University. Second process was analyzed the nutritive value of sugar cane waste, in Laboratory of ruminant and chemical feed at Faculty of Animal Husbandry, Padjajaran University, Bandung.

A Complete Randomized Design with four treatments and three replications was carried out. The experimental diets were : EO (control), E1 (waste of sugar cane $+7,5 \mathrm{ml} E M-4$ ), E2 (waste of sugar cane $+15 \mathrm{ml} E M-4$ ), E3 (waste of sugar cane $+22,5 \mathrm{ml} E M-4$ ). Each treatment was added with rice straw $20 \%$ of dried weight sugar cane waste. The parameters measured were dry matter, crude fiber, crude protein, NFE and crude fat.

The results of this research showed that the treatment improved significantly to dry matter, crude fiber, crude protein, NFE and crude fat. The conclusi-on of the research was treatment by addition EM-4 $15 \mathrm{ml}$ give the best result in all treatments.
\end{abstract}

Key Words : Effective Organism-4, nutrition quality, fermentation, sugar cane waste.

\section{PENDAHULUAN}

\subsection{Latar Belakang}

Peningkatan produktivitas ternak sangat tergantung dari tiga faktor yaitu pakan, pembibitan dan tata laksana. Pakan bagi ternak ruminansia tergantung dari penyediaan hijauan dalam jumlah cukup, berkualitas tinggi dan berkesinambungan sepanjang tahun. Rendahnya nilai gizi dan fluktuasi produksi hijauan pakan sepanjang tahun merupakan masalah penyediaan pakan di Indonesia sampai saat ini. Salah

satu usaha mengatasi masalah tersebut adalah dengan memanfaatkan bahanbahan pakan inkonvensional seperti limbah pertanian, peternakan dan perkebunan ${ }^{1}$.

Pemanfaatan limbah pertanian dan limbah industri pengolahan hasil pertanian yang berserat tinggi diperkirakan mampu menyediakan kira-kira $66 \%$ dari total kebutuhan ternak ruminansia ${ }^{2)}$. Potensi yang demikian besar belum dimanfaatkan 
secara optimal oleh peternak sebagai pakan ternak. Pemanfaatan limbah pertanian untuk pakan ternak ruminansia baru sekitar 39\% dari potensinya selebihnya dibuang, dibakar atau digunakan untuk keperluan selain ternak ${ }^{3}$. Salah satu limbah perkebunan yang jumlahnya cukup besar, namun belum termanfaatkan adalah ampas tebu atau bagasse tebu.

Dari jumlah total tebu yang digiling akan diperoleh bagasse sekitar $30-35 \%{ }^{4)}$ dan dari luas satu hektar tanaman tebu akan diperoleh 180 ton biomass pertahun. Dari 180 ton biomass tersebut, akan diperoleh 38 ton pucuk tebu dan 72 ton bagasse yang mampu menyediakan pakan untuk ternak sapi sebanyak 17 ekor (bobot 250-450 $\mathrm{kg})^{2)}$

Bagasse tebu belum termanfaatkan secara maksimal mengingat kendala yang dihadapi adalah ketersediaan dari produksi tebu itu sendiri. Bagasse tebu seperti umumnya limbah pertanian lainnya, memiliki nilai nutrisi dan nilai biologis yang cukup rendah. ${ }^{4}$ Bagasse adalah limbah padat industri gula tebu yang mengandung selulosa. Potensi bagasse di Indonesia cukup besar, pada 2007 luas tanaman tebu di indonesia mencapai 404.653 Ha. ${ }^{5}$ ) Dari luasan tersebut dapat diperoleh sekitar 29.135.016 ton bagasse/tahun atau setara dengan 6.879.101 ekor sapi (ST).

Serat kasar dari bagasse terdiri dari selulosa, pentosan dan lignin. ${ }^{1)}$ Kandungan lignin yang cukup tinggi dalam serat kasar menyebabkan kecernaan bagasse tebu rendah. Rendahnya kandungan zat gizi merupakan faktor pembatas penggunaan bagasse sebagai pakan ternak ruminansia serta tidak memenuhi persyaratan yang baik untuk kebutuhan hidup pokok, apalagi untuk produksi. ${ }^{6)}$

EM-4 merupakan kultur campuran dari berbagai mikroorganisme yang menguntungkan antara lain: Lactobacillus $s p$, bakteri fotosintetik, bakteri asam laktat, Streptomycetes $s p$, jamur pengurai selulosa, bakteri fosfat dan ragi. EM-4 dibidang peternakan digunakan sebagai inokulan untuk meningkatkan keragaman dan populasi mikroorganisme yang menguntungkan di dalam saluran pencernaan, memperbaiki aktivitas pencernaan, meningkatkan kesehatan ternak, menekan bakteri pathogen dan menghilangkan bau pada kandang. EM-4 juga dapat menguraikan bahan organik komplek menjadi sederhana dan mampu melonggarkan ikatan selulosa. ${ }^{7)}$

Effective Microorganism-4 (EM-4) adalah suatu kultur campuran berbagai mikroorganisme bermanfaat terutama bakteri fotosintetik dan bakteri asam laktat, ragi, actinomycetes, dan jamur fermentasi yang dapat digunakan sebagai inokulan untuk meningkatkan mikroba tanah. ${ }^{8)}$, sedangkan EM-4 dikulturkan pada media cair dengan $\mathrm{pH} 4,5^{(4)}$.

EM-4 dapat diterapkan dalam pengolahan limbah, menghilangkan bau atau polusi dimana pada limbah ternak dicampur dengan air minum untuk memperbaiki mikroorganisme yang ada pada perut ternak sehingga pertumbuhan dan produksi ternak akan meningkat. ${ }^{7)}$ Penggunaan EM-4 sebanyak $6 \%$ telah mampu menurunkan kandungan serat kasar dari $34,60 \%$ menjadi $24,07 \%$ pada pakan berserat tinggi yaitu rumput raja. ${ }^{2)}$

Mikroorganisme utama EM-4 terdiri dari (1) Bakteri fotosintesis (bakteri fototropik), membentuk zat-zat yang bermanfaat dari sekresi akar-akar tumbuhan, bahan organik dan atau gas-gas yang berbahaya (misalnya Hidrogen Disulfida), dengan menggunakan sinar matahari dan panas bumi sebagai energi. Zat-zat bermanfaat tersebut berupa asam amino, asam nukleat, zat-zat bioaktif dan gula yang semuanya mempercepat pertumbuhan dan perkembangan tanaman. (2) Bakteri asam laktat menghasilkan asam laktat dari gula. Bakteri asam laktat dapat menekan pertumbuhan mikroorganisme yang merugikan dan meningkatkan perombakan bahan-bahan organik disamping dapat melonggarkan dan memutus ikatan lignin 
dan selulosa serta memfermentasikannya tanpa menimbulkan pengaruh merugikan yang diakibatkan oleh bahan-bahan organik yang tidak terurai. (3) Ragi, sekresi ragi adalah substrat untuk EM-4 seperti asam laktat dan Actinomycetes, (4) Actinomycetes, strukturnya merupakan bentuk antara dari bakteri dan jamur, menghasilkan zat antimikroba dari asam amino yang dikeluarkan oleh bakteri fotosintesis dan bahan organik, serta (5) Jamur fermentasi. ${ }^{8)}$

Produk fermentasi bahan organik dengan menggunakan EM-4 disebut dengan bokashi. Berbagai cara untuk meningkatkan keragaman mikroba, penggunaan beberapa macam bahan organik sangat dianjurkan. Bahan organik yang sering digunakan misalnya jerami padi, dedak, sekam, serbuk gergaji, kotoran ternak, zeolit dan lain-lain. Kondisi lingkungan yang mendukung proses fermentasi dengan menggunakan EM-4 yaitu pada $\mathrm{pH}$ rendah (3-4), kadar garam dan gula tinggi, kadar air yang sedang $30-35 \%$, tidak panas dan tidak berbau busuk. ${ }^{\text {) }}$

Konsep dari mikroba EM-4 itu sendiri adalah mengisolasi dan menyeleksi berbagai macam mikroorganisme yang berbeda-beda untuk meningkatkan kegunaan dari tanah dan tanaman. Dan itulah yang dihasilkan oleh mikroba-mikroba EM-4 yaitu mikroba yang dapat hidup bersama dalam kondisi yang bercampur dan antar mikroba juga dapat berkompetisi secara baik. Mikrobamikroba di dalam EM-4 ini merupakan spesies mikroba yang dapat kita temui di alam bebas ini. ${ }^{8)}$

\subsection{Tujuan Penelitian}

Penelitian ini bertujuan untuk memanfaatkan limbah bagasse tebu melalui perlakuan teknik fermentasi dengan menggunakan Effective Microorganisme-4 (EM-4), sehingga kualitas limbah bagasse tebu dapat ditingkatkan untuk pakan ternak.

\section{METODOLOGI}

Metode yang digunakan adalah
Rancangan Acak Lengkap (RAL) dengan 4 perlakuan dan 3 ulangan, perlakuan terdiri dari:

$\mathrm{E} 0=$ Bagasse tebu (substrat) $1 \mathrm{~kg}$

$\mathrm{E} 1=$ Bagase tebu $1 \mathrm{~kg}+\mathrm{EM}-47,5 \mathrm{ml}$

$\mathrm{E} 2=$ Bagase tebu $1 \mathrm{~kg}+\mathrm{EM}-415 \mathrm{ml}$

$\mathrm{E} 3=$ Bagase tebu $1 \mathrm{~kg}+\mathrm{EM}-422,5 \mathrm{ml}$

Model linier rancangan $\mathrm{Y}=\mu+£ i j+\mu \mathrm{ij}$

Dimana :

$\mathrm{Y}=$ Nilai perlakuan

$\mu=$ Nilai rerata harapan

$£ i j=$ Pengaruh perlakuan ke $\mathrm{i}$ ulangan ke $\mathrm{j}$

$\mu \mathrm{ij}=$ Pengaruh galat.10)

\section{HASIL DAN PEMBAHASAN}

Kualitas kandungan serat kasar fermentasi bagasse tebu dengan menggunakan EM-4 di sajikan pada Tabel 1 .

Tabel 1. Rataan persentase serat kasar pada fermentasi bagasse tebu dengan menggunakan EM-4

\begin{tabular}{|l|c|}
\hline Perlakuan & $\begin{array}{c}\text { Kandungan Serat } \\
\text { Kasar(\%) }\end{array}$ \\
\hline E0 & $43.643 \mathrm{a}$ \\
\hline E1 & $41.320 \mathrm{ab}$ \\
\hline E2 & $34.250 \mathrm{c}$ \\
\hline E3 & $40.737 \mathrm{~b}$ \\
\hline
\end{tabular}

Keterangan: Superskrip yang berbeda pada kolom yang sama menunjukkan pengaruh perlakuan berbeda nyata $(P<0.05)$

Berdasarkan hasil analisis keragaman menunjukkan bahwa level pemberian EM-4 memberikan pengaruh yang berbeda nyata $(P<0.05)$ terhadap kandungan serat kasar hasil fermentasi bagasse tebu. Hasil yang diperoleh setelah dilakukan uji lanjut menunjukkan bahwa E0 memberikan pengaruh berbeda nyata $(P<0,05)$ dengan perlakuan E2 dan E3 tetapi tidak berbeda nyata $(P>0.05)$ dengan perlakuan E1. Sementara itu pada perlakuan E1 
memberikan pengaruh berbeda tidak nyata $(P>0.05)$ dengan E3 tapi berbeda nyata $(P<0.05)$ dengan E2. Pada perlakuan E2 memberikan pengaruh berbeda nyata dengan E0, E1 dan E3.

Penambahan EM-4 dengan level $7,5 \mathrm{ml}$ yaitu pada perlakuan $\mathrm{E} 1$ belum mempengaruhi perubahan kandungan serat kasar pada bagasse tebu meskipun dari Tabel. 1 dapat kita lihat terjadi penurunan serat kasar. Hal ini dikarenakan jumlah level pemberian EM-4 masih terlalu kecil sehingga bakteri dan mikroba lain yang terkandung dalam EM-4 yang berguna untuk meregangkan ikatan lignoselulosa dan lignohemiselulosa juga sedikit sehingga serat kasar yang terlarut tidak terlalu banyak. Penurunan serat kasar bagasse tebu yang difermentasi dengan EM-4 ini juga dikarenakan di dalam EM-4 terdapat bakteri pengurai serat atau selulosa, yaitu Azoprillum sp, Azobacteri sp dan Rhizobium $s p$ serta jamur fermentasi lainnya. ${ }^{11)}$

Perlakuan pada level pemberian EM-4 sebesar $15 \mathrm{ml}$ menghasilkan penurunan serat kasar yang terbesar dan berbeda nyata dibandingkan 3 perlakuan lainnya, dimana perbandingan antara E2 $=34.25 \%$ dan E0= 43.643 yaitu sebesar $27.4 \%$. Penurunan serat kasar ini disebabkan karena jumlah EM-4 yang digunakan sudah optimal sehingga terjadi proses peregangan ikatan lignohemiselulosa yang menyebabkan terlarutnya bahan-bahan organik yang menghasilkan karbohidratkarbohidrat sederhana. Dinyatakan juga, bahwa penurunan lignin dan sellulosa akibat kerja dari bakteri asam laktat yaitu lactobacillus $s p$ yang akan mendegradasi bahan organik yaitu dengan melonggarkan ikatan lignohemisellulosa sehingga enzimenzim bisa menguraikan zat-zat makanan menjadi lebih sederhana. ${ }^{12)}$ Perlakuan E3 menunjukkan kembali terjadi peningkatan serat kasar, yang diduga disebabkan karena mikroba-mikroba yang terkandung di dalam EM-4 tidak lagi bekerja dengan optimal memecah ikatan lignosellulosa dan lignohemisellulosa. Hal ini diduga karena jumlah mikroba dan asupan energi bagi perkembangan mikroba tidak lagi tercukupi, sehingga pemecahan serat kasar tidak terjadi secara optimal. Dilaporkan juga, bahwa apabila nutrisi untuk mikroba terlalu rendah maka kehidupan mikroba akan terganggu dan akhirnya mati, dan setelah mikroba mati maka tidak lagi terjadi ${ }^{13)}$. Kualitas kandungan protein kasar fermentasi bagasse tebu dengan menggunakan EM-4 di sajikan pada Tabel 2.

Tabel 2. Rataan persentase kandungan Protein Kasar pada fermentasi bagasse tebu

\begin{tabular}{|l|l|}
\hline Perlakuan & $\begin{array}{l}\text { Kandungan Protein } \\
\text { Kasar }(\%)\end{array}$ \\
\hline E0 & $2.483 a$ \\
\hline E1 & $3.747 \mathrm{~b}$ \\
\hline E2 & $4.183 \mathrm{c}$ \\
\hline E3 & $3.390 \mathrm{~b}$ \\
\hline
\end{tabular}

Keterangan : Superskrip yang berbeda pada kolom yang sama menunjukkan pengaruh perlakuan berbeda nyata $(\mathrm{P}<0.05)$.

Berdasarkan hasil analisis keragaman menunjukkan bahwa pemberian EM-4 memberikan pengaruh berbeda nyata $(\mathrm{P}<0.05)$ terhadap kandungan protein kasar hasil fermentasi bagasse tebu. Hasil uji lanjut menunjukkan perlakuan E0 memberikan pengaruh yang berbeda nyata $(P<0.05)$ dibandingkan tiga perlakuan lainnya. Perlakuan E1 dan perlakuan E3 memberikan pengaruh berbeda nyata $(P<0.05)$ dibandingkan E2 sementara perlakuan E1 dan perlakuan E3 memberikan pengaruh berbeda tidak nyata $(P>0.05)$.

Pemberian EM-4 pada berbagai level yang semakin tinggi didalamfermentasi bagasse tebu diharapkan dapat meningkatkan protein kasar dari bagasse tebu. Level pemberian EM-4 yang optimal dapat meningkatkan protein kasar pada fermentasi bagasse tebu yaitu pada level $15 \mathrm{ml}$. Peningkatan protein kasar 
ini diduga karena selama proses fermentasi bagasse tebu dengan EM-4, sel-sel mikroba yang terdapat di dalam EM-4 berkembang biak dengan baik dengan menggunakan sumber energi dari substrat itu sendiri, dalam perkembangannya sel-sel mikrobia tersebut merupakan unsur-unsur protein sehingga meningkatkan protein kasar dari bagasse tebu itu sendiri Dilaporkan juga ${ }^{13)}$, bahwa dalam proses pembuatan bokashi terjadi peningkatan protein kasar yang diakibatkan oleh terbentuknya protein sel tunggal pada saat setelah fermentasi.

Semakin banyak pertumbuhan bakteri maka sumbangan asam amino untuk pembentukan protein juga akan semakin meningkat yang berasal dari bakteri tersebut. Hal ini karena EM-4 dapat menyediakan molekul organik sederhana seperti asam amino dan memperbaiki bahan organik dari limbah ${ }^{9}$. Ditambahkan juga, bahwa selama proses fermentasi mikroba akan mengeluarkan enzim dimana enzim tersebut adalah protein dan mikroba itu sendiri juga merupakan sel tunggal ${ }^{7}$.

Pemberian level EM-4 pada level $22,5 \mathrm{ml}$ atau pada perlakuan E3 terjadi penurunan kandungan protein kasar apabila dibandingkan dengan perlakuan E2 namun penurunan pada E3 ini berbeda tidak nyata dengan E1. Hal Ini diduga karena pada level $22.5 \mathrm{ml}$ level pemberian EM-4 sudah melewati batas level optimal. Hal ini disebabkan karena jumlah mikroba yang sudah mencukupi sehingga mikroba tidak mampu lagi untuk mendegradasikan protein kasar dengan optimal. Diungkapkan pula, bahwa penurunan protein kasar disebabkan oleh aktivitas proteolitik oleh jamur ${ }^{14)}$. Mikrobia tersebut akan memfermentasikan protein pada bagasse tebu sehingga akan menurunkan protein kasar hasil fermentasi dengan hasil samping berupa karbondioksida dan ammonia. Degradasi protein kasar tersebut secara enzimatis oleh mikrobia menghasilkan asam amino yang secara cepat teroksidasi menghasilkan ammonia yang mudah menguap, sehingga menyebabkan penurunan protein kasar hasil fermentasi ${ }^{15}$. Kandungan BETN fermentasi bagasse tebu dengan menggunakan EM-4 di sajikan pada Tabel 3 .

Tabel 3. Rataan persentase kandungan BETN pada fermentasi bagasse tebu dengan menggunakan EM-4

\begin{tabular}{|l|l|}
\hline Perlakuan & \multicolumn{1}{|c|}{$\begin{array}{c}\text { Kandungan BETN } \\
(\%)\end{array}$} \\
\hline E0 & $48.143 a$ \\
\hline E1 & $48.193 a$ \\
\hline E2 & $52.676 \mathrm{~b}$ \\
\hline E3 & $49.207 a$ \\
\hline
\end{tabular}

Keterangan : Superskrip yang berbeda pada kolom yang sama menunjukkan pengaruh perlakuan berbeda nyata $(\mathrm{P}<0.05)$

Berdasarkan hasil analisis keragaman menunjukkan bahwa peningkatan level pemberian EM-4 memberikan pengaruh berbeda nyata $(P<0.05)$ terhadap kandungan BETN hasil fermentasi bagasse tebu dengan menggunakan EM-4. Hasil yang diperoleh setelah dilakukan uji lanjut menunjukkan bahwa peningkatan level pemberian EM-4 memberikan pengaruh berbeda tidak nyata $(P>0.05)$ terhadap kandungan BETN pada perlakuan E0, E1 dan E3, tetapi berbeda nyata $(P<0.05)$ dengan perlakuan $E 2$.

Penambahan EM-4 pada level 7,5 $\mathrm{ml}$ belum memberikan pengaruh terhadap perubahan kandungan BETN bagasse tebu terfermentasi meskipun dari Tabel.4 dapat kita lihat terjadi peningkatan BETN hal ini disebabkan karena kondisi dari BETN sangat dipengaruhi oleh kandungan dari serat kasar. Pada penggunaan EM-4 pada level $15 \mathrm{ml}$ yaitu pada perlakuan E2 terjadi peningkatan kadar BETN yang berbeda nyata $(P<0.05)$ terhadap ketiga perlakuan lainnya, ini semua berkaitan dengan penurunan kandungan serat kasar yang disebabkan karena terjadinya proses fermentasi yang di sebabkan oleh EM-4. 
Bakteri dan mikroba lain yang terdapat di dalam EM-4 melonggarkan dan memutuskan ikatan selulosa, hemiselulosa dan lignin yang menyebabkan karbohidrat sederhana meningkat. Dinyatakan pula ${ }^{16)}$, bahwa peningkatan kadar BETN dipengaruhi oleh karena hilangnya lignin, selulosa dan hemiselulosa dalam proses fermentasi yang mengakibatkan penurunan kandungan serat kasar sehingga dengan menurunnya kandungan serat kasar tersebut secara otomatis dapat meningkatkan kandungan BETN.

Perlakuan E3 kadar BETN mengalami penurunan kembali, hal ini dikarenakan pada perlakuan E3 bakteri asam laktat yang terdapat pada EM-4 tidak bekerja dengan maksimal karena bakteri asam laktat yang yang dihasilkan tidak mencukupi untuk memecah ikatan lignoselulosa dan lignohemiselulosa yang mengakibatkan kandungan serat kasar menjadi meningkat dan mengakibatkan kandungan BETN menjadi turun. Dilaporkan juga, bahwa kandungan BETN akan menurun seiring dengan bertambahnya hemisellulosa dalam proses fermentasi ${ }^{17}$. Rataan kandungan lemak kasar fermentasi bagasse tebu dengan menggunakan EM-4 di sajikan pada Tabel 4.

Tabel 4. Rataan persentase kandungan Lemak kasar pada fermentasi bagasse tebu dengan menggunakan EM-4

\begin{tabular}{|l|l|}
\hline Perlakuan & $\begin{array}{l}\text { Kandungan Lemak } \\
\text { Kasar (\%) }\end{array}$ \\
\hline E0 & $1.513 \mathrm{a}$ \\
\hline E1 & $2.677 \mathrm{~b}$ \\
\hline E2 & $3.427 \mathrm{c}$ \\
\hline E3 & $2.873 \mathrm{bc}$ \\
\hline
\end{tabular}

Keterangan : Superskrip yang berbeda pada kolom yang sama menunjukkan pengaruh perlakuan berbeda nyata $(\mathrm{P}<0.05)$
Berdasarkan hasil analisis keragaman menunjukkan bahwa peningkatan level pemberian EM-4 memberikan pengaruh berbeda nyata $(P<0.05)$ terhadap kandungan lemak kasar hasil fermentasi bagasse tebu dengan menggunakan EM-4. Hasil yang diperoleh setelah dilakukan uji lanjut menunjukkan bahwa perlakuan E0 berbeda nyata $(P<0.05)$ dibandingkan ketiga perlakuan lainnya, perlakuan E3 memberikan pengaruh tidak nyata $(P>0.05)$ pada perlakuan E1 dan E2.

Peningkatan lemak kasar pada penelitian ini berpengaruh sampai perlakuan E3. Peningkatan lemak kasar ini di mungkinkan karena jumlah bakteri yang terkandung di dalam bagasse tebu yang berasal dari EM-4 selama fermentasi, sehingga terjadi peningkatan kadar lemak kasar sebesar $126.5 \%$ (dari $1.513 \%$ sampai 3.427 ) pada bagasse tebu terfermentasi sampai pada perlakuan E2 (EM-4 15ml). Hal ini sesuai dengan penelitian, yang melaporkan bahwa jumlah bakteri pada pelepah sawit yang berasal dari poultry manure yang lebih sedikit menyebabkan jumlah lemak yang terbentuk lebih sedikit. ${ }^{18)} \mathrm{Hal}$ ini diperkuat oleh hasil penelitian, yang menyatakan bahwa substrat padat ampas-gula dapat meningkatkan lemak $82,39 \%$ dan protein $32,92 \%$ dan juga semua substrat (padat/cair) dapat menghasilkan asam lemak. ${ }^{19)}$

Pada perlakuan E3 mulai terjadi penurunan kandungan lemak kasar. Penurunan kandungan lemak ini terjadi karena selama pada proses fermentasi mikroba yang terdapat pada EM-4 berkembang biak sehingga jumlah bakteri yang memanfaatkan lemak juga semakin banyak, ini menyebabkan kandungan lemak kasar bagasse tebu terfermentasi mengalami penurunan. Mikroba yang bekerja selama proses fermentasi memanfaatkan lemak yang terdapat pada bagasse tebu sebagai sumber energinya dalam menghidrolisa asam-asam lemak, karena pada saat melakukan metabolisme sebagian karbohidrat, protein dan lemak akan digunakan sebagai sumber energi. ${ }^{20)}$ 


\section{KESIMPULAN DAN SARAN}

Level terbaik dari pemakaian EM-4 dalam proses fermentasi bagasse tebu adalah $15 \mathrm{ml}$, namun demikian perlu dilakukan penelitian secara in-vitro dan invivo untuk mengetahui tingkat kecernaan dan palatabilitas fermentasi bagasse tebu dengan penambahan EM-4 pada dosis $15 \mathrm{ml}$.

\section{UCAPAN TERIMA KASIH}

Ucapan terima kasih kami sampaikan kepada Adil Abdillah, yang telah banyak membantu dalam pelaksanaan penelitian dan kepada semua pihak yang terlibat, baik dalam pengolahan data maupun pelaksanaan di lapangan.

\section{DAFTAR PUSTAKA}

1. Muchtar, K.S., Tedjocahyono., Kurniawan, Y., dan Murdianto, U., 1985. Potensi hasil samping industri gula dalam menunjang industri peternakan di Indonesia. Proseding Pemanfaatan Limbah Pertania Untuk Makanan Ternak. Yogyakarta. P. 133-243.

2. Leng, L.A., 1995. Short course in ruminant nutrition. Faculty of Animal Science. Andalas University Padang. West Sumatera, Indonesian. From 28 - 29 July 1995.

3. Siregar, A.R., dan Talib, C., 1992. Penggemukan sapi bali dan ongole di Tawaehi, Sulawesi Tengah. Proseding Agro Industri Peternakan di Pedesaan. BPT. Bogor.

4. Reksohadiprodjo, S., 1984. Bahan Makanan dan Limbah Pertanian dan Industri, BPFE, Yogyakarta.

5. Buku Statistik Perkebunan Tahun 2006-2008, Direktorat Jenderal Perkebunan, Departemen Pertanian, Jakarta.

6. Gohl. 1975. Tropical Feed. Feed Information Summaries and Nutritive Values. FAO. United Nation, Rome. 433-445.
7. Annah, L., dan Lindajati, T., 1987. Peningkatan kadar protein onggok dengan cara fermentasi media padat. Jurnal Penenlitian dan Pembangunan Pertanian. Vol. III (4) : 335-341

8. APNAN. 1995. Pembangunan Pertanian Alami Akrab Lingkungan dengan Microorganism Effective dalam EM-4 Application Manual for APNAN Countries. The First Edition. APNAN.

9. Wididana, G.N., 1998. Bokashi dan Fermentasi. IPSA. Jakarta.

10. Steel.R.G.D., and Torrie, J.H., 1993. Prinsip dan Prosedur Statistik Suatu Pendekatan Biometrik, Edisi ke III. PT Gramedia Pustaka Utama, Jakarta.

11. Higa, T., dan Widana, G.H., 1996. Tanya Jawab Teknologi Effective Microorganism-4. TKNFS. PT. Songgolangit Persada. Jakarta.

12. Higa, T., 1996. Pembangunan Pertanian Alami Akrab Lingkungan dengan Mikroorganism Efektif (Teknologi EM). Bumi Lestari. Jakarta.

13. Utomo, R., Soejono, M., and Schiere, J.B., 1987. Review of duration and concentration urea treated straw on digestibility. Proceedings Bioconversion Project Second Workshop on Crop Residues for Feed and Other Purposes. 16-17 Nopember 1987, Grati, Pasuruan.

14. McDonald, P., 1981. The Biochemistry of Silage. John Wiley and Sons, New York, USA.

15. Suharsono, M., 1986. Biokimia. Jilid II. Edisi ke-8. Gadjah Mada University Press, Yogyakarta.

16. Tillman, D.A., Hari, H., Soedomo, R., Soeharto, P., Soekanto, L., 1998. IImu Makanan Ternak Dasar. Gadjah Mada University Press. Yogyakarta. 
17. Chuzaemi, S., dan Soejono, M., 1987. Pengaruh urea dalam amoniasi terhadap komposisi kimia dan nilai gizi jerami padi untuk sapi peranakan ongole. Proceedings Bioconversion Project Second Workshop on Crops Residues for Feed and Other Purposes. Grati, Pasuruan, Jatim. 16-17 Nopember 1987.

18. Sari, I.I., 2006. Level pemberian urea dalam amoniasi pelepah sawit terhadap kandungan bahan kering, serat kasar, protein kasar, BETN dan lemak Kasar. Tesis. Faluktas Pertanian UNSRI. Palembang
19. Erwin, A., 2002. Pemanfaatan limbah kelapa sawit sebagai penghasil sumber asam lemak omega-3. (Online). (http: //digilib.itb.ac.id/search. phplemak\&start41)

20. Winarno, F.G., dan Fardiaz. 1990. Biofermentasi dan Biosintesis Protein. Angkasa. Bandung. 